\title{
Pasados y presentes de la violencia en Colombia - Estudio sobre las Comisiones de Investigación (1958- 2011 ). Jefferson Jaramillo M. Bogotá: Editorial Universidad Javeriana, 2014. 274 pp.
}

\section{Fernando Cubides Cipagauta ${ }^{1}$}

Universidad Nacional de Colombia, Bogotá, Colombia ${ }^{2}$ fcubides@etb.net.co

"En el plano de la historia de larga duración, historia y sociología no es que se respalden (seria quedarse corto): se confunden" F. Braudel: La historia y las ciencias sociales.

Magíster en Ciencia Política de la Universidad de los Andes. Sociólogo, de la Universidad Nacional de Colombia

2 Profesor titular jubilado 
El libro que aquí reseñamos es una buena muestra de que el esfuerzo de comprensión de la situación colombiana y la profusa serie de modalidades de violencia que caracterizan su historia contemporánea, se ha llevado a un campo reflexivo, a un esfuerzo de introspección, de recapitulación y análisis de las investigaciones más importantes, y a su relación con las demandas de conocimiento que les dan sentido. Es una literatura que pudiéramos llamar secundaria, no en relación a su validez intrínseca sino a que toma como objeto los propios estudios hechos sobre ese asunto cardinal. Lo descriptivo del título define bien el intento. Se trata además de una tesis doctoral en la que el autor se vale de un nuevo instrumental y con un nuevo lenguaje, ha tenido oportunidad de alternar e intercambiar con personas de su mismo nivel de formación pero de otras latitudes. Un antídoto contra la idea parroquial del excepcionalismo colombiano. Y tiene el cuidado de distanciarse de aquellas actitudes que procuran conciliar de modo sumario con lo 'políticamente correcto'.

Jaramillo Marín adopta la secuencia cronológica; comienza su análisis entonces con aquella Comisión creada en los mismos orígenes del Frente Nacional, sus vicisitudes y uno de sus productos, el más intelectual: el libro pionero La violencia en Colombia (junio de 1962). Se cuida eso si del anacronismo, es decir de hacer exigencias retrospectivas, de pedir peras al olmo, por el contrario se ubica en la época, acorde con lo que podían poseer como información y como formación aquellos pioneros. Es vigilante respecto a una comparación entre las distintas Comisiones y sus respectivos informes que haga abstracción de los condicionantes con los que contaron, de las restricciones y presiones específicas a las que estuvieron, o han estado sujetas. En otras palabras, entiende que a la primera de las Comisiones no se le podría pedir que en su labor se centrara en las víctimas (cuando de lo que se trataba en principio era acotar responsabilidades y comenzar a discurrir sobre unas causas generales e identificar a los principales victimarios), a la de los violentólogos de 1987, sometida a plazos tan cortos, mal podría habérsele pedido ejercicios de memoria.

Como a la Comisión de Memoria reciente sí se le puede atribuir una endeblez en la interpretación histórica, no se le podría demandar lo que en rigor le habrá de corresponder a una Comisión de Verdad: 
que discurra y discierna lo que en un sentido colectivo se pueda entender como verdad histórica, y así por consiguiente. En esa ponderación y relativización histórica, el trabajo aquí reseñado es juicioso, sutil. Y se advierte un contraste no planeado, generacional diriamos, entre el tono enfático, grandilocuente, del prologuista -quien fuera el coordinador de las dos últimas Comisiones- y el tono analítico del trabajo, justamente retrospectivo y en un lenguaje sobrio que parece rehuir en la mayor parte del contenido, las formulaciones altisonantes; un lenguaje a nuestro ver propio de la generación más reciente, por lo visto desencantada de "esas grandes palabras que nos han hecho tan desgraciados" como dice el personaje de Joyce.

No considera el autor en fin que la grandilocuencia sea una virtud aplicable al asunto arduo que han acometido las sendas Comisiones y somete a crítica todos los discursos, los desglosa y se muestra capaz de interrogar de nuevo las evidencias acumuladas. Aun cuando en eso de la elocuencia, de cuando en cuando se permita sus efusiones: según él los pioneros "combinan la visceralidad subjetiva con la ignominia estructural” (p. 102). El desliz de prosopopeya es breve y predomina lo sobrio del análisis, en conjunto es muy controlado en cuanto a la adjetivación. Y sobre todo predomina el esfuerzo, la tensión por la elaboración teórica del problema: ¿Qué es la memoria? ¿Acaso memoria e historia son lo mismo? ¿O más bien puede ocurrir que el culto al recuerdo, la evocación de los sufrimientos se haga a expensas del estudio racional de los acontecimientos históricos? La memoria contra la historia. Lo cual se ha dicho, por cierto, en relación con el Holocausto y la Shoá y el modo en que el Estado de Israel los conmemora oficialmente y comporta una lección útil para nuestro caso ${ }^{3}$.

Al acotar el tema, el autor ha hallado una veta nueva del análisis y su contribución es mostrar de modo cabal y sintético a la generación más reciente la complejidad de la violencia como problema de conocimiento, a través de los alcances y limitaciones de las Comisiones que se han abocado a él, buscando aplicarlo en la práctica..

\footnotetext{
3 Ver al respecto: A vueltas con la cuestión judía_de Élizabeth Roudinesco, Ed. Anagrama, Barcelona, 2011.
} 
Hay eso sí, inevitables concesiones al ritualismo académico de las tesis doctorales; la serie de entrevistas a los integrantes de las Comisiones recientes, por ejemplo, para el efecto los entrevistados resultan ser multitud y no aportan nuevas ideas o evidencias y concluye uno que están en función de lo que el Director de Tesis o sus jurados pudieran exigir.

Además, como en todos los ejercicios retrospectivos, el tiempo ha hecho lo suyo y apreciamos mejor lo ocurrido hace más de medio siglo, está más decantado y han aflorado por cierto evidencias que no fueron accesibles a sus coetáneos. Hay pasajes breves en que se muestra capaz de elaboración teórica, reflexivos en el mejor sentido. Instructivos, como dijimos, en cuanto a lo que signifique la memoria, la verdad, la responsabilidad colectiva e individual, los modos de atribuirla y la gruesa diferencia entre la verdad judicial en el marco de la justicia transicional y el tipo de conocimiento que un investigador de las ciencias sociales pretende construir y legar como precipitado válido. El recurso al plural en el título no solo obedece a la prudencia analítica (no confundir modalidades, huir de la designación genérica e insustancial, en suma: no ontologizar la violencia) sino también al hecho de que hay un par de libros con títulos parecidos, aunque en singular.

Tal vez en razón de su juventud, y dado que redacta su tesis en el exterior, se alcanzan a deslizar algunas inexactitudes: "Debemos recordar que Betancur y Barco privaron a los militares de la jefatura del Ministerio de Defensa" (p.117) afirma y tal vez lo que quiso decir es que cambiaron a los titulares de ese Ministerio, que siguieron siendo militares, hasta la administración Gaviria quien por fin designó a un civil para el cargo. Cosas menudas, harto compensadas por aquellos pasajes, breves, puntuales, en que hay un grado de elaboración teórica; el autor se muestra a la altura del asunto, de un asunto tan crucial y que ha dado lugar a una montaña de publicaciones, nacionales e internacionales, sin que podamos decir, ni mucho menos, que se trate de un asunto 'sobre-diagnosticado'.

La última frase del libro es todo un programa de investigación, como si el autor se hubiese propuesto delinear su trabajo futuro y 
fuera consciente de que lo que nos ha presentado aquí es tan solo su preámbulo ${ }^{4}$.

Y una mención especial merecen los anexos, nos ubican en la perspectiva adecuada: la comparación internacional, y vienen siendo muy útiles para quien quiera retomar el análisis, para todas aquellas personas que se hayan formulado como problema la relación entre el conocimiento y su aplicaciones prácticas, sus efectos en un asunto tan arduo, tan virulento, como el de las modalidades de violencia.

4 "De todas formas queda abierta la invitación [...] a examinar con cuidado cómo se llega a las comunidades, qué se extrae de ellas, cómo se compila lo extraído en un informe, cómo se retorna ese producto, y cómo se discute en la escena pública". 